Scientific Article

\title{
PENGETAHUAN ETNOMEDISIN MASYARAKAT BALI TENTANG PARE (Momordica charantia L.; CUCURBITACEAE): SEBUAH KAJIAN KEPUSTAKAAN
}

\author{
Balinese ethnomedicinal knowledge of 'Pare' (Momordica charantia L.; Cucurbitaceae): A review study
}

\author{
Gebby A. E. Oktavia ${ }^{1 *}$, Fitriana Hayyu Arifah², Nissa Arifa ${ }^{3}$, Wawan Sujarwo ${ }^{3}$ \\ 1Pusat Penelitian Konservasi Tumbuhan dan Kebun Raya - LIPI, Purwodadi, Pasuruan, Jawa Timur 67163 \\ ${ }^{2}$ Fakultas Farmasi - Universitas Gadjah Mada, Sekip Utara, Yogyakarta 55281 \\ 3Pusat Penelitian Biologi - LIPI, Jalan Raya Jakarta-Bogor Km. 46, Cibinong, Jawa Barat 16911
}

\section{Informasi Artikel \\ Diterima/Received : 10 Juli 2020 \\ Disetujui/Accepted : 23 November 2020 \\ Diterbitkan/Published : 1 Desember 2020 \\ *Koresponden E-mail : gebb001@lipi.go.id \\ DOI: $\underline{\text { https://doi.org/10.14203/bkr.v23i3.644 }}$ \\ Cara mengutip \\ Oktavia GAE, Arifah FH, Arifa N, Sujarwo W. 2020. Pengetahuan etnomedisin masyarakat bali tentang pare (Momordica charantia L.; Cucurbitaceae) : Sebuah kajian kepustakaan. Buletin Kebun Raya 23(3): 179-186. DOI: https://doi.org/10.14203/bkr.v23i3.644}

\section{Kontributor}

\section{Kontributor Utama/Main author:}

Gebby A. E. Oktavia

Fitriana Hayyu Arifah

Nissa Arifa

Wawan Sujarwo

Keywords: Bali, loloh, Momordica charantia, pharmacological activities

Kata Kunci: aktivitas farmakologi, Bali, loloh, Momordica charantia

\begin{abstract}
Momordica charantia is a herbaceous climber, in which the Indonesian people know the species with the name of "pare". This plant is used by the Balinese to make loloh (Balinese traditional herbal drink) to relieve heartburn, fainting and anti-diabetes. This study aims to reveal the uses of $M$. charantia and its pharmacological activities. The method used in data collection was using scientific databases, such as Google Scholar, Science Direct, Scopus, and Springer Portal. The obtained data were then qualitatively analyzed. The results showed that $M$. charantia can be used as traditional medicine by the Balinese for several conditions namely limuh (fainting), barah/ beteg (swelling), pain dan chickenpox. M. charantia contains various pharmacological activities, such as antidiabetic, anticancer, antibacterial, antifertility, antiviral, antiulcer, anthelmintic, and antimalaria activities.
\end{abstract}

\begin{abstract}
Abstrak
Momordica charantia merupakan tumbuhan herba merambat, yang dikenal masyarakat Indonesia dengan nama "pare". Tumbuhan ini secara umum dimanfaatkan masyarakat Bali untuk membuat loloh (minuman herbal tradisional Bali) untuk meredakan panas dalam, mengobati limuh dan diabetes. Penelitian ini bertujuan untuk mengetahui pemanfaatan $M$. charantia oleh masyarakat Bali serta aktivitas farmakologinya. Metode yang digunakan dalam pengumpulan data adalah dengan menggunakan scientific databases, seperti google scholar, science direct, portal scopus, dan springer. Data yang diperoleh selanjutnya dianalisis dengan pendekatan deskriptif kualitatif. Hasil menunjukkan bahwa masyarakat Bali menggunakan $M$. charantia sebagai obat tradisional pada beberapa kondisi yaitu limuh (pingsan), barah/ beteg (bengkak), nyeri, dan cacar. $M$. charantia mengandung aktivitas farmakologi, seperti antidiabetes melitus, antikanker, antibakteri, antifertilitas, antivirus, anti-ulcer, antelminitik, dan antimalaria.
\end{abstract}

\section{PENDAHULUAN}

Kekayaan biodiversitas dan keanekaragaman suku di Indonesia membuat Indonesia kaya akan pengetahuan dan pemanfaatan tumbuhan obat (Elliott \& Brimacombe 1987; Mitra et al. 2007; Silalahi et al. 2015; Khairiah et al. 2017). Hal ini sudah berlangsung berabad-abad dan dibuktikan dengan adanya bukti relief pada dindingdinding candi di Pulau Jawa dan naskah lontar usada di Pulau Bali. Lontar usada merupakan naskah pengobatan herbal masyarakat Bali yang ditulis di daun lontar dan dipraktekkan oleh para balian usada (ahli pengobatan tradisional Bali) (McCauley 1988).

Pada abad ke-19, para ahli botani dan dokter dari pemerintah kolonial Hindia Belanda sangat tertarik untuk mempelajari praktek pengobatan herbal di wilayah Nusantara. Sejarah tumbuhan obat Indonesia ini erat kaitannya dengan sejarah berdirinya Kebun Raya Bogor. Profesor Caspar George Carl Reinwardt diangkat oleh Pemerintah Belanda menjadi Direktur Pertanian, Seni, dan Pendidikan untuk Pulau Jawa pada tahun 1816. Beliau merupakan salah satu orang yang tertarik pada penelitian tumbuhan obat. Reinwardt melakukan eksplorasi tumbuhan dan menanamnya di kebun botani yang kini dikenal dengan nama Kebun Raya Bogor (Weber 2014).

Pols (2009) menyebutkan bahwa dokter-dokter Belanda berperan penting dalam promosi obat-obat tradisional Indonesia. Hal ini diperkuat oleh bukti publikasi ilmiah yang berkaitan dengan penggunaan 
tanaman sebagai obat herbal, seperti Short Account of the Medicinal Plants of Java oleh Thomas Horsfield (1816); Praktische waarnemingen over eenige Javaansche geneesmiddelen oleh Friedrich August Carl Waitzdi (1829), dan Indische planten en haar geneeskracht oleh Mevrouw J. Kloppenburg-Varsteegh (1907) yang semuanya membahas tumbuhan obat masyarakat pribumi. Selain itu, Kloppenburg-Varsteegh juga membuat buku tentang tanaman obat yaitu Boekoe obat obat (1916), Boekoe djampi (1916) dan petundjuk lengkap mengenai tanamtanaman di Indonesia dan khasiatnya sebagai obat-obatan tradisionil (1983). Selain itu, diperkuat pula dengan adanya buku berjudul "Select Indonesian Medicinal Plants" oleh van Steenis-Kruseman (1953) (Elliott \& Brimacombe 1987).

Salah satu suku di Indonesia yang memiliki kekayaan pengetahuan tradisional tentang tumbuhan obat adalah masyarakat Bali dan lebih dari 350 jenis tumbuhan digunakan untuk pengobatan (Tengah et al. 1995, Sujarwo et al. 2015, Sujarwo et al. 2016). Satu diantaranya yang cukup terkenal adalah "pare" (Momordica charantia). Jenis ini merupakan tumbuhan herba merambat yang termasuk suku Cucurbitaceae, dapat tumbuh mulai dari dataran rendah hingga ketinggian $1.300 \mathrm{~m}$ dpl. (Holm et al. 1997; Lim 2012). M. charantia berasal dari India dan telah banyak tersebar di wilayah tropis lainnya seperti Afrika Timur, Amerika Selatan, Asia, dan Karibia (Takhtajan 1986; Taylor 2002).

Masyarakat Bali memanfaatkan daun M. charantia untuk membuat loloh, minuman herbal untuk meringankan penyakit diabetes (Tengah et al. 1995), meredakan panas dalam (Sujarwo et al. 2015), dan mengobati limuh (Arsana 2019).. Buahnya juga telah populer dikonsumsi dengan cara diiris tipis, dikeringkan, lalu dimasak sebagai teh herbal di beberapa negara Asia, seperti Filipina, India, Malaysia, Tiongkok, dan Vietnam (Lim 2012; Nagarani et al. 2014). Ekstrak daun dan batangnya a digunakan untuk pengembangan obat modern pada kalangan komunitas ilmiah global (Beloin et al. 2005; Lim 2012). Penelitian aktivitas farmakologi menunjukkan bahwa berbagai bagian tumbuhan $M$. charantia memiliki efek antidiabetes melitus (Virdi et al. 2003; Joseph \& Jini 2013), pencegah kanker (Grover \& Yadav 2004), antibakteri (Braca et al. 2008), antifertilitas (Adewale et al. 2014), dan aktivitas farmakologi lainnya.

Bagian $M$. charantia yang dapat dimanfaatkan untuk pengobatan meliputi semua bagian tanaman, yaitu akar, batang, buah, bunga, biji, dan daun (Grover \& Yadav 2004; Lim 2012; Giovannini et al. 2016), sedangkan di Bali hanya terbatas pada daun dan buah saja (Sujarwo et al. 2015). Penelusuran M. charantia pada lontar usada Bali perlu dilakukan untuk mengetahui pemanfaatannya dalam pengobatan tradisional. Ulasan ini bertujuan untuk mengetahui pemanfaatan $M$. charantia oleh masyarakat Bali dan memberi informasi terkait dengan aktivitas farmakologinya.

\section{BAHAN DAN METODE}

\section{Bahan dan alat penelitian}

Bahan penelitian ini berasal dari buku, jurnal ilmiah, tulisan populer dan semi populer, serta laporan penelitian maupun non penelitian milik perorangan, instansi, maupun dari situs internet. Pengumpulan data dilakukan dengan menggunakan scientific databases, seperti google scholar, science direct, portal scopus, dan springer.

\section{Tahapan pelaksanaan dan analisis data}

Nama tumbuhan divalidasi berdasarkan online database dari portal Plants of the World Online (www.plantsoftheworldonline.org). Data tentang pengetahuan etnomedisin masyarakat Bali mengenai penggunaan $M$. charantia dan aktivitas farmakologinya ditabulasikan, kemudian dianalisis dengan pendekatan deskriptif kualitatif.

\section{HASIL DAN PEMBAHASAN}

Momordica charantia merupakan tumbuhan yang tidak bergantung pada musim, sehingga tidak pernah menggugurkan daun dan berbuah sepanjang tahun. Meskipun bukan tumbuhan asli dari Kawasan Malesia (Malaysia, Indonesia, Singapura, Brunei, Filipina, dan Papua Nugini), pemanfaatan buah dan daun M. charantia dapat menjadi keunggulan tersendiri karena kelimpahannya sehingga dapat menjadi tanaman budidaya produktif (Novi \& Rizki 2015). Untuk lebih mengenal dan memahami bentuk perawakan $M$. charantia, ilustrasi botaninya ditampilkan pada Gambar 1.

Ahmad et al. (2016) menyatakan bahwa $M$. charantia sangat baik dikonsumsi sebagai pelengkap makan, obat tradisional, dan suplemen kesehatan. Bagian yang paling banyak dimanfaatkan dalam pengobatan tradisional adalah daun, karena besarnya kelimpahannya jika dibandingkan dengan bagian lainnya (Oktavia et al. 2017). Selain itu, daun juga merupakan bagian yang mudah diekstraksi untuk mendapatkan metabolit sekunder yang terkandung di dalamnya. 

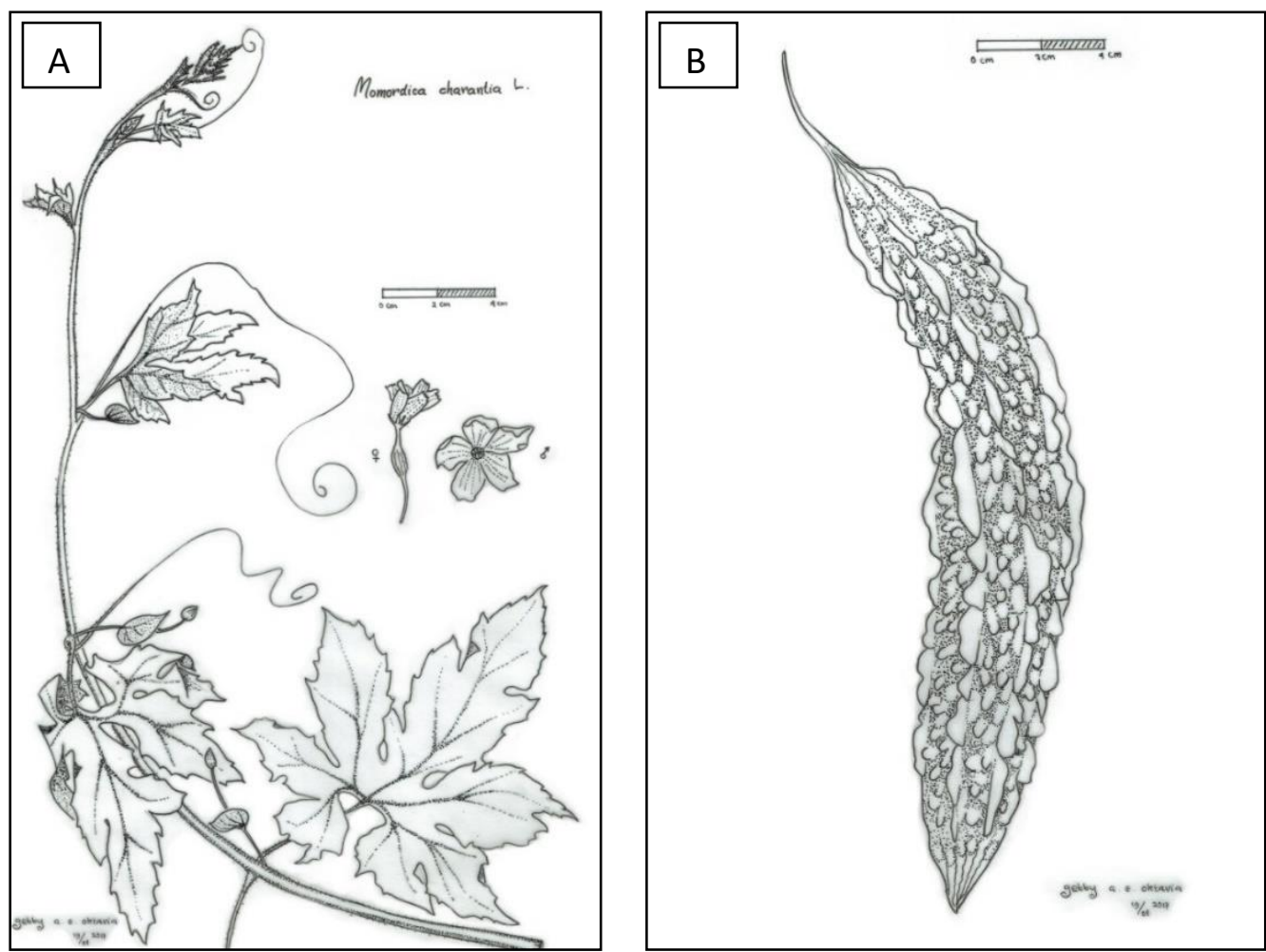

Gambar 1. Ilustrasi botani Momordica charantia. A. bagian daun, batang, sulur dan bunga; B (bagian buah) (Gambar: ilustrasi oleh Oktavia GAE)

Momordica charantia dalam bahasa Bali disebut dengan paya/paya kuwuh/paya kutuh (Sujarwo et al. 2019; Basabali 2020). Penelusuran informasi pemanfaatan M. charantia dilakukan pada beberapa naskah lontar usada (Tabel 1). Jumlah lontar usada sampai saat ini tidak dapat dihitung secara pasti karena tersebar di berbagai lokasi dan banyak yang dimiliki secara pribadi oleh balian usada (McCauley 1988).

Tabel 1. Pemanfaatan M. charantia pada naskah Lontar Usada

\begin{tabular}{|c|c|c|c|c|c|}
\hline \multirow[b]{2}{*}{ No. } & \multirow[b]{2}{*}{ Nama lontar usada } & \multirow[b]{2}{*}{ Cara pemanfaatan } & \multicolumn{2}{|c|}{ Kondisi / jenis penyakit } & \multirow[b]{2}{*}{ Sumber referensi } \\
\hline & & & $\begin{array}{l}\text { yang disebut } \\
\text { dalam lontar }\end{array}$ & gejala medis & \\
\hline 1 & Usada taru pramana & daun dijadikan loloh & limuh & $\begin{array}{l}\text { pingsan, tidak enak } \\
\text { badan }\end{array}$ & $\begin{array}{l}\text { Sukersa et al. (2017), } \\
\text { Arsana (2019) }\end{array}$ \\
\hline 2 & Usada gede & $\begin{array}{l}\text { daun dicampur dengan } \\
\text { kelapa yang dibakar dan } \\
\text { disemburkan }\end{array}$ & barah & bengkak & Depdikbud (1991) \\
\hline 3 & $\begin{array}{l}\text { Usada tenung tanya } \\
\text { lara }\end{array}$ & $\begin{array}{l}\text { daun dijadikan boreh/ } \\
\text { parem }\end{array}$ & $\begin{array}{l}\text { tiwang } \\
\text { lombok/ rasa } \\
\text { sakit datang } \\
\text { dan pergi }\end{array}$ & nyeri & Sudiasta et al. (1991) \\
\hline 4 & Usada kacacar & $\begin{array}{l}\text { batang dan daun dijadikan } \\
\text { obat balur }\end{array}$ & cacar & $\begin{array}{l}\text { kulit gatal, bentol, } \\
\text { berair lalu pecah } \\
\text { dan akan berwarna } \\
\text { kemerahan }\end{array}$ & Sutrisna et al. (2019) \\
\hline 5 & Usada thiwang & $\begin{array}{l}\text { buah dihaluskan } \\
\text { digunakan sebagai bedak }\end{array}$ & beteg & bengkak pada kaki & Arsana et al. (2020) \\
\hline
\end{tabular}

Hasil penelusuran lontar usada menunjukkan beberapa jenis penyakit dapat disembuhkan dengan $M$. charantia. Penyakit dalam pengobatan lontar usada dibedakan menjadi penyakit sekala dan penyakit niskala. Penyakit sekala merupakan penyakit yang gejalanya terlihat nyata dan dapat dijelaskan dengan ilmu medis, sedangkan penyakit niskala adalah penyakit yang dipercaya berhubungan dengan unsur gaib (Arsana 2019). Penelitian ilmiah hanya dapat memberi penjelasan terbatas pada jenis penyakit sekala. 
Momordica charantia dimanfaatkan sebagai loloh untuk mengobati limuh. Loloh merupakan minuman herbal yang digunakan untuk mengobati berbagai penyakit (Sujarwo et al. 2015). Jenis penyakit yang disebutkan dalam lontar banyak yang belum dapat disesuaikan dengan bahasa medis diantaranya adalah penyakit limuh. Sukersa et al. (2017) menyebutkan bahwa limuh sama dengan kondisi tidak enak badan dan pingsan. M. charantia secara tradisional digunakan untuk mengobati orang yang pingsan karena udara panas (Chusna 2016). Namun sampai saat ini belum ditemukan rujukan pustaka ilmiah yang melaporkan uji biologi $M$. charantia sebagai obat pingsan.

Momordica charantia juga disebutkan dapat digunakan untuk mengobati barah dan beteg. Barah merupakan kondisi bengkak lokal pada bagian tubuh (Sridana 2019). Istilah ini hampir serupa dengan istilah beteg yang disebut dalam Usada Thiwang yang berarti bengkak pada kaki (komunikasi pribadi 2020). Hal ini mengindikasikan bahwa $M$. charantia dimanfaatkan oleh masyarakat Bali sebagai anti-bengkak. Hal ini sesuai dengan penelitian modern yang membuktikan bahwa ekstrak M. charantia memiliki aktivitas antiinflamasi (Parawansah et al. 2016; Rahmawati et al. 2020).

Momordica charantia juga dimanfaatkan sebagai obat tradisional untuk penghilang rasa nyeri oleh masyarakat Bali. Jenis ini memiliki aktivitas analgesik yang telah diuji secara in vivo (Fauzan \& Zuhrotun 2019). Selain itu, M. charantia juga digunakan untuk obat tradisional penyakit cacar. Hal ini serupa dengan yang dilakukan oleh masyarakat di Kabupaten Gowa dan Kabupaten Enrekang, Sulawesi Selatan yang menggunakan daun M. charantia sebagai olesan pada penyakit cacar (Husain 2015; Wahidah \& Husain 2018).

Tumbuhan ini juga dimanfaatkan secara tradisional di beberapa negara untuk pengobatan dyslipidemia (kandungan kadar lemak dalam darah yang terlalu tinggi), infeksi mikroba, dan agen sitotoksik beberapa tipe kanker di Afrika (Ahmed et al. 2001; Chaturvedi et al. 2004; Chrubasik et al. 2007; Oishi et al. 2007; Tcheghebe et al. 2016). Biji, buah, daun, dan akarnya dimanfaatkan untuk pengobatan gangguan pencernaan (sluggish digestion), menstimulasi proses menstruasi (menstrual stimulation), penyembuhan luka, penurun demam, dan hipertensi (Leung 1984; Tcheghebe et al. 2016). Di Guyana, rebusan daunnya digunakan sebagai antivirus untuk campak, hepatitis, dan demam (Jagessar et al. 2008; Tcheghebe et al. 2016). Di Uganda, campuran daun dan akarnya digunakan untuk abortifacient (aborsi) dan ekbolik (merangsang kontraksi uterus) (Chhabra et al. 1989; Tcheghebe et al. 2016). Di India, M. charantia digunakan dalam praktek aborsi, mengontrol kelahiran, meningkatkan jumlah air susu ibu (ASI), mengobati gangguan menstruasi, malaria, asam urat, pneumonia, dan rematik. Tumbuhan ini biasanya dikonsumsi sebagai sayuran (Grover \& Yadav 2004; Tcheghebe et al. 2016). Di Kamerun, sari buahnya diklaim dapat menurunkan kasus Pyorrhea (infeksi gusi yang merusak gigi) (Tcheghebe et al. 2016). Berbagai pemanfaatan M. charantia sebagai obat tradisional telah mendorong berbagai penelitian aktivitas farmakologi.

\section{Antidiabetes melitus}

Momordica charantia dilaporkan memiliki aktivitas farmakologi antidiabetes melitus tipe 2, bahkan penelitiannya sudah sampai tingkat molekuler. Kapsul ekstrak buah $M$. charantia menunjukkan selektivitas untuk pengambat $11 \beta$ hidroksisteroid dehidrogenase tipe 1 (11ß-HSD1) untuk pengobatan obesitas dan diabetes melitus (DM) tipe 2, namun belum diketahui senyawa yang bertanggungjawab pada aktivitas ini (Blum et al. 2012). Penelusuran mekanisme aksi ekstrak buahnya mampu menginaktivasi nuclear factor- $K B$ (NF-kB) dan phospho-c-Jun N-terminal kinase (JNK), serta mengaktivasi insulin receptor substrate-1 (IRS-1) dan Akt pada model hewan uji DM tipe 2 resisten insulin (Yang et al. 2015).

Polisakarida buah $M$. charantia yang difermentasi mampu meningkatkan aktivitas antidiabetes melitus pada tikus yang diinduksi diet tinggi lemak dan streptozotosin dibandingkan dengan yang tidak difermentasi, yaitu dengan memperbaiki kondisi hiperglikemia, hiperinsulin, hiperlipid, dan stres oksidatif (Gao et al. 2018). Saponin buah $M$. charantia diketahui memiliki efek antidiabetes melitus tipe 2 pada tikus yang diinduksi diet tinggi lemak dan streptozotosin (STZ), yaitu dengan meregulasi metabolisme lipid, stres oksidatif, dan jalur persinyalan insulin pada ekspresi IRS-1 dan Akt (Jiang et al. 2020). Ekstrak protein buah $M$. charantia juga diketahui memiliki efek antidiabetes melitus tipe 2, yaitu mekanisme memicu penyerapan glukosa dengan up-regulating glucose transporter4 (GLUT4) dan phosphorylated AMP-activated protein kinase (pAMPK) pada jaringan adiposa dan otot skeletal (Poovitha \& Parani 2017).

\section{Antikanker}

Momordica charantia juga memiliki kandungan zat antikanker dari hasil penelusuran mekanisme molekulernya. Triterpenoid pada buahnya diketahui memiliki efek anti-hepatik fibrosis (mencegah kerusakan liver) pada sel murine hepatic stellate $\mathrm{t}-\mathrm{HSC} / \mathrm{Cl}-6$ dan antihepatoma (anti-kanker hepar) pada sel HepG2 dan Hep3B, serta dilaporkan bahwa karaviloside III memiliki efek anti-hepatik fibrosis (mencegah kerusakan liver), dan anti-hepatoma (anti-kanker hepar) paling baik dibanding 
senyawa triterpenoid lain (Yue et al. 2019). Protein MAP30 pada biji $M$. charantia secara in vitro memiliki aktivitas dalam meregulasi jalur caspase-8 dan caspase- 9 pada apoptosis (kematian sel) sel HepG2 dan secara in vivo pada mencit yang sudah diinduksi sel kanker HepG2 menunjukkan efektivitas antitumor (Fang et al. 2012). Kuguacin J, senyawa triterpenoid pada daun $M$. charantia mampu menghambat pertumbuhan sel pada fase $\mathrm{G} 1$ yang ditandai dengan penurunan cyclin D1 dan E, cyclindependent kinases (Cdk2 dan $\mathrm{Cdk} 4)$, antigen nuklir sel proliferasi (PCNA), dan peningkatan protein p21 dan p27, serta mekanisme lain dengan meningkatkan Bax/Bcl-2 dan Bad/Bcl-xL serta menurunkan survivin sehingga menginduksi apoptosis (kematian sel) pada sel kanker prostat LNCaP. Kuguacin J juga dilaporkan menghambat invasi dan migrasi sel kanker prostat PC3 dengan menekan jumlah matrix metalloproteinase (MMP)-2, MMP-9, dan urokinase plasminogen activator (UPA) (Pitchakarn et al. 2012).

\section{Antibakteri}

Aktivitas antibakteri $M$. charantia terdapat pada buah, daun, dan biji. Ekstrak buah $M$. charantia yang dilapisi dengan nanopartikel perak memberikan efek antibakteri yang lebih baik pada bakteri gram positif dibandingkan bakteri gram negatif dan menurunkan pertumbuhan biofilm pada bakteri (Malaikozhundan et al. 2016). Ekstrak buahnya yang diformulasikan dengan polimer polivinil alkohol memberikan efek antibakteri baik pada gram positif maupun gram negatif (Hashmi et al. 2020). Ekstrak etanolik daun $M$. charantia mampu memberikan efek mirip dengan klorpromazin pada pemberian yang dikombinasi dengan kanamisin, gentamisin, dan neomisin pada bakteri yang resisten aminoglikosida yaitu multi-resistance bacteria (MRSA) seperti SA358 (Coutinho et al. 2010). Minyak atsiri bijinya mengandung komponen utama trans-nerolidol (61,6\%) yang sensitif menghambat Staphylococcus aureus dengan nilai MIC $<500 \mu \mathrm{g} / \mathrm{mL}$ (Braca et al. 2008).

\section{Antifertilitas}

Beberapa bagian $M$. charantia mengandung zat antifertilitas untuk hewan uji jantan maupun betina. Ekstrak metanolik bijinya yang diujikan pada tikus jantan dewasa mampu menurunkan produksi sperma secara dose-dependent dengan penurunan jumlah dan motilitas (pergerakan) sperma, volume testis, dan testosteron (Yama et al. 2011). Ekstrak etanolik-air biji M. charantia menunjukkan efek duration-dependent (tergantung durasi) dalam menurunkan bobot dan volume testis, serta diameter tubulus seminiferus dan area potongan melintang tubulus, namun terjadi peningkatan profil jumlah per area, densitas lebar, dan densitas jumlah tubulus seminiferus pada tikus jantan dewasa (Yama \& Duru 2011). Ekstrak air daun M. charantia memberikan efek antifertilitas pada tikus betina dewasa secara dosedependent (tergantung dosis) dengan penurunan estrogen dan progesteron (Adewale et al. 2014). Ekstrak metanolik biji $M$. charantia mampu memberikan antiovulasi dan antiimplantasi pada aborsi awal, serta defisiensi pertumbuhan prenatal yang diujikan pada tikus betina dewasa (Amah et al. 2012).

\section{Antivirus}

Kandungan alpha dan beta-momorcharin, lektin, dan MAP 30 pada $M$. charantia yang diuji secara in vitro memiliki aktivitas antivirus terhadap Epstein-Barr, herpes, HIV, coxsackievirus B3, dan virus polio (Grover \& Yadav 2004). Selain itu, terdapat juga protein yang berpotensi sebagai antivirus terhadap influenza A (H1N1) pada ekstrak buahnya. Virus H1N1 ini merupakan salah satu virus yang pernah menjadi pandemi beberapa tahun silam (Pongthanapisith et al. 2013; Purwitasari et al. 2015).

\section{Antiulcer (Anti tukak lambung)}

Momordica charantia telah terbukti memiliki aktivitas antiulcer (anti tukak lambung) terhadap dua model ulkus (luka) yang berbeda. Dalam satu penelitian, momordin Ic (10 mg/kg, p.o.) berpotensi menghambat etanol yang diinduksi lesi (jaringan abnormal) mukosa lambung (Matsuda et al. 1999; Grover \& Yadav 2004). Dalam penelitian lain, bubuk kering buah $M$. charantia dalam madu yang disaring menunjukkan aktivitas antiulcerogenik. Selain itu, ekstrak buah dengan etanol juga menunjukkan antiulcer yang signifikan terhadap $\mathrm{HCl}$-EtOH yang diinduksikan secara ulcerogenesis ke dalam tikus yang diberi indometasin dan diethyldithiocarbamate yang diinduksi pada ulkus (Gurbuz et al. 2000; Grover \& Yadav 2004). Yesilada et al. (1999) dan Grover \& Yadav (2004) menyatakan bahwa $M$. charantia memiliki aktivitas anti Helicobacter pylori, yang juga bermanfaat untuk aktivitas antiulcer.

\section{Aktivitas Antelmintik (Obat Cacing)}

Lal et al. (1976) dan Grover \& Yadav (2004) menyebutkan bahwa $M$. charantia memiliki aktivitas antelmintik terhadap cacing Ascaridia galli. Tjokropranoto et al. (2011) juga melaporkan bahwa ekstrak etanol daun M. charantia memiliki aktivitas antekmintik terhadap cacing Ascaris suum. Kedua jenis cacing ini merupakan penyebab askariasis yang dikenal sebagai infeksi cacing usus. 


\section{Antimalaria}

Ekstrak buah $M$. charantia memiliki aktivitas antimalaria yang diuji secara in vitro, meskipun aktivitasnya termasuk dalam kategori lemah (Kohler et al. 2002; Grover \& Yadav 2004). Pada pengujian aktivitas antimalaria secara in vivo, ekstrak buah $M$. charantia memiliki aktivitas antimalaria kategori sedang terhadap Plasmodium vinckei-petteri 279 (Munoz et al. 2000; Grover \& Yadav 2004). Selain buah, ekstrak daunnya juga memiliki aktivitas antimalaria (Christy et al. 2016).

\section{KESIMPULAN}

Masyarakat Bali menggunakan $M$. charantia sebagai obat tradisional pada beberapa kondisi yaitu limuh (pingsan), barah/ beteg (bengkak), nyeri dan cacar. $\mathrm{Hal}$ ini sesuai dengan penelitian modern yang menyebutkan bahwa $M$. charantia memiliki aktivitas antiinflamasi, antinyeri, dan digunakan sebagai obat cacar. Di beberapa negara, $M$. charantia juga dimanfaatkan untuk pengobatan gangguan pencernaan, penyembuhan luka, penurun demam, hipertensi, gangguan menstruasi, malaria, asam urat, pneumonia, dan rematik. Selain itu, $M$. charantia mengandung aktivitas antidiabetes melitus, antikanker, antibakteri, antifertilitas, antivirus, antiulcer, antelmintik dan antimalaria.

\section{UCAPAN TERIMA KASIH}

Penulis mengucapkan terima kasih kepada bapak I Nyoman Peneng yang telah membantu dalam menyediakan material tumbuhan Momordica charantia.

\section{DAFTAR PUSTAKA}

Adewale OO, Oduyemi OI, Ayokunle O. 2014. Oral administration of leaf extracts of Momordica charantia affect reproductive hormones of adult female Wistar rats. Asian Pacific Journal of Tropical Biomedicine 4(suppl 1): S521-S524.

Ahmad N, Noorul H, Zeeshan A, Mohd Z, Seikh Z. 2016. Momordica charantia: For traditional uses and pharmacological actions. Journal of Drug Delivery \& Therapeutics 6(2): 1-5.

Ahmed I, Lakhani MS, Gillet M, John A, Raza H. 2001. Hypotriglyceridemic and hypocholestrolemic effects of anti-diabetic Momordica charantia fruit juice on islet morphology in the pancreas of the sttreptozotocindiabetic rat. Diabetes Research and Clinical Practice 40: 145-151.
Arsana IN. 2019. Keragaman Tanaman Obat dalam Lontar "Taru Pramana" dan Pemanfaatannya untuk Pengobatan Tradisional Bali. Jurnal Kajian Bali 9(1): 241-262.

Arsana IN, Sudiartawan IP, Sudaryati NLG. 2020. Pengobatan tradisional Bali usadha tiwang. Jurnal Bali Membangun Bali 1 (2): 111-124.

Amah Cl, Yama OE, Noronha CC. 2012. Infecund evaluation of cycling female Sprague-Dawley rats: An aftermath treatment with Momordica charantia seed extract. Middle East Fertility Society Journal 17(1): 37-41.

Basabali. 2020. Plants of Eiseman's Book. http://basabali.org/3278-2/ (diakses 10 Oktober 2020).

Beloin N, Gbeassor M, Akpagana K, Hudson J, de Soussa K, Koumaglo K, Arnason JT. 2005. Ethnomedicinal uses of Momordica charantia (Cucurbitaceae) in Togo and relation to its phytochemistry and biological activity. Journal of Ethnopharmacology 96: 49-55.

Blum A, Loerz C, Martin HJ, Staab-Weijnitz CA, Maser E. 2012. Momordica charantia extract, a herbal remedy for type 2 diabetes, contains a specific $11 \beta$-hydroxysteroid dehydrogenase type 1 inhibitor. The Journal of Steroid Biochemistry and Molecular Biology 128: 51-55.

Braca A, Siciliano T, D’Arrigo M,Germanò MP. 2008. Chemical composition and antimicrobial activity of Momordica charantia seed essential oil. Fitoterapia 79(2): 123-125.

Chaturvedi P, George S, Milingayo M, Tripathi YB. 2004. Short commucication: Effect of Momordica charantia on lipid profile and oral glucose tolerance in diabetic rats. Phytotherapy research 18: 954-956.

Chhabra SC, Mahunnah RLA, Mshiu EN. 1989. Plants in traditional medicine in Eastern Tanzania. II. Angiosperms (Capparidaceae to Ebenaceae). Journal of Ethnopharmacology 25: 339-359.

Chusna N. 2016. Uji aktivitas spermisida ekstrak etanol biji pare gajih (Momordica charantia $\mathrm{L}$ ) terhadap sperma manusia secara in vitro. Jurnal Surya Media 1(2): 34-40.

Christy AO, Mojisola COC, Taiwo EO, Ola OO. 2016. The antimalaria effect of Momordica charantia L. and Mirabilis jalapa leaf extracts using animal model. Academic Journals 10(24): 344-350.

Chrubasik JE, Roufogalis BD, Chrubasik D. 2007. Evidence of effectiveness of herbal anti inflammatory drugs in the treatment of painful osteoarthritis and chronic low back pain. Phytotherapy research 21: 675-683.

Coutinho HDM, Costa JGM, Falcão-Silva VS, Siqueira-Júnior JP, Lima EO. 2010. Effect of Momordica charantia L. in the resistance to aminoglycosides in methicilin-resistant Staphylococcus aureus. Comparative Immunology, Microbiology and Infectious Diseases 33(6): 467-471.

Depdikbud. 1991. Usada Gede. Departemen Pendidikan dan Kebudayaan Direktorat Jenderal Kebudayaan Direktorat Sejarah dan Nilai Tradisional Proyek Penelitian dan Pengkajian Kebudayaan Nusantara 1991-1992.

Elliott S, Brimacombe J. 1987. The medicinal plants of Gunung Leuser National Park, Indonesia. Journal of Ethnopharmacology 19(3): 285-317. 
Fang EF, Zhang CZY, Wong JH, Shen JY, Li CH, Ng TB. 2012. The MAP30 protein from bitter gourd (Momordica charantia) seeds promotes apoptosis in liver cancer cells in vitro and in vivo. Cancer Letters 324(1): 66-74.

Fauzan MR, Zuhrotun A. 2019. Review artikel: Beberapa tanaman yang memiliki aktivitas analgesic secara in vitro. Farmaka 17(1): 123-133.

Gao H, Wen JJ, Hu JL, Nie QX, Chen HH, Xiong T, Nie SP, Xie MY. 2018. Polysaccharide from fermented Momordica charantia L. with Lactobacillus plantarum NCU116 ameliorates type 2 diabetes in rats. Carbohydrate Polymers 201: 624-633.

Giovannini P, Howes MJR, Edwards SE. 2016. Medicinal plants used in the traditional management of diabetes and its sequelae in Central America: A review. Journal of Ethnopharmacology 184: 58-71.

Grover JK, Yadav SP. 2004. Pharmacological actions and potential uses of Momordica charantia: a review. Journal of Ethnopharmacology 93(1): 123-132.

Gurbuz I, Akyuz C, Yesilada E, Sener B. 2000. Anti-ulcerogenic effect of Momordica charantia L. fruits on various ulcer models in rats. Journal of Ethnopharmacology 71: 77-82.

Hashmi M, Ullah S, Kim IS. 2020. Electrospun Momordica charantia incorporated polyvinyl alcohol (PVA) nanofibers for antibacterial applications. Materials Today Communications 24.

Holm L, Doll J, Holm E, Pancho J, Herberger J. 1997. World weeds: natural histories and distribution. John Wiley and Sons, Inc., New York.

Husain NA. 2015. Studi etnobotani dan identifikasi tumbuhan berkhasiat obat berbasis pengetahuan lokal di Kabupaten Enrekang. Skripsi, Jurusan Budidaya Pertanian, Fakultas Pertanian, Universitas Hasanudin.

Jagessar RC, Mohamed A, Gomes G. 2008. An evaluation of the antibacterial and antifungal activity of leaf extracts of Momordica charantia against Candida albicans, Staphylococcus aureus and Escherichia coli. Nature and Science 6(1): 1-14.

Jiang S, Xu L, Xu Y, Guo Y, Wei L, Li X, Song W. 2020. Antidiabetic effect of Momordica charantia saponins in rats induced by high-fat diet combined with STZ. Electronic Journal of Biotechnology 43: 41-47.

Joseph B, Jini D, 2013. Antidiabetic effects of Momordica charantia (bitter melon) and its medicinal potency. Asian Pacific Journal of Tropical Disease 3(2): 93-102.

Khairiah A, Nisyawati, Silalahi M. 2017. Biodiversity of medicinal plants by Minangkabau ethnic in Guguak Sarai, West Sumatera, Indonesia. Presented at the International Symposium On Current Progress In Mathematics And Sciences 2016 (ISCPMS 2016): Proceedings of the 2nd International Symposium on Current Progress in Mathematics and Sciences 2016, Depok..

Kohler I, Janett-Siems K, Siems K, Hernandez MA, Ibarra RA, Berendsohn WG, Bienzle U, Eich E. 2002. In vitro antiplasmodial investigation of medicinal plants from $\mathrm{El}$ Savador. Zeitschrift fur Naturforschung (section-C) 57: 277-281.
Lal J, Chandra S, Raviprakash V, Sabir M. 1976. In vitro anthelmintic action of some indigenous medicinal plants on Ascardia galli worms. Indian Journal of Pharmaceutical Science Review Research 1(2): 95-97.

Leung AY. 1984. Chinese Herbal Remedies. Universe Book, New York.

Lim TK. 2012. Edible Medicinal And Non-Medicinal Plants. Springer Netherlands, Dordrecht.

Malaikozhundan B, Vaseeharan B, Vijayakumar S, Sudhakaran R, Gobi N, Shanthini G. 2016. Antibacterial and antibiofilm assessment of Momordica charantia fruit extract coated silver nanoparticle. Biocatalysis and Agricultural Biotechnology 8: 189-196.

Matsuda H, Li Y, Yoshikawa M. 1999. Roles of capsaicin-sensitive sensory nerves, endogenous nitric oxide, sulfhydryls and prostaglandins in gastroprotection by momordin Ic, and oleanolic acid aligoglycoside, on ethanol-induced gastric mucosal lesions in rats. Life Science 65: 27-32.

McCauley AP. 1988. Healing Texts and Healing Techniques in Indigenous Balinese Medicine. Soc. Sci. Med 27(8): 779787.

Mitra R, Mitchell B, Gray C, Orbell J, Coulepis T, Muralitharan MS. 2007. Medicinal Plants of Indonesia. Asia-Pacific Biotech News 11(11): 726-743.

Munoz V, Souvain M, Bourdy G. 2000. The search for natural bioactive compounds through a multidisciplinary approach in Bolivia: Part II. Antimalaria activity of some plants used by Mosetena. Indian Journal of Ethnopharmacology 69: 139-155.

Nagarani G, Abirami A, Siddhuraju P. 2014. Food prospects and nutraceutical attributes of Momordica species: A potential tropical bioresources-A review. Food Science and Human Wellness 3: 117-126.

Novi, Rizki. 2015. Pertumbuhan Vegetatif Tanaman Pare (Momordica charantia L.) yang Diberi Air Cucian Beras pada Berbagai Konsentrasi. Bioconcetta 1(2): 67-73.

Oishi Y, Sakamoto T, Udagawa H, Taniguchi H, Kobayashi-hattori K, Ozawa Y, Takita T. 2007. Inhibition of Increases in Blood Glucose and serum neutral fat by Momordica charantia saponin fraction. Bioscience, Biotechnology, and Biochemistry 71(3): 735-740.

Oktavia GAE, Darma IDP, Sujarwo W. 2017. Studi etnobotani tumbuhan obat di kawasan sekitar Danau BuyanTamblingan, Bali. Buletin Kebun Raya 20(1): 1-16.

Parawansah, Wahyuni, Mahmudah Z. 2016. Uji efek antipiretik dan antiinflamasi ekstrak etanol buah pare (Momordica charantia L.) terhadap Mencit Jantan. Medula: jurnal ilmiah Fakultas Kedokteran Universitas Halu Oleo 4(1): 309-315.

Pitchakarn P, Suzuki S, Ogawa K, Pompimon W, Takahashi S, Asamoto M, Limtrakul P, Shirai T. 2012. Kuguacin J, a triterpeniod from Momordica charantia leaf, modulates the progression of androgen-independent human prostate cancer cell line, PC3. Food and Chemical Toxicology 50(3-4): 840-847.

Pols H. 2009. European physicians and botanist, indigenous herbal medicine in the Dutch East Indies, and colonial 
networks of meditation. East Science, Technology and Society: an International Journal 3: 173-208.

Pongthanapisith V, Ikuta K, Puthavathana P, Leelamanit W. 2013. Antiviral protein of Momordica charantia L. inhibits different subtypes of Influenza A. Evidencebased Complementary and Alternative Medicine 1: 1-6.

Poovitha S, Parani M. 2017. Protein extract from the fruit pulp of Momordica charantia potentiate glucose uptake by upregulating GLUT4 and AMPK. Journal of Functional Foods 37: 507-512.

Purwitasari N, Studiawan H, Rahmawati K. 2015. Aktivitas antivirus dari ekstrak methanol buah Momordica charantia. Jurnal Farmasi dan IImu Kefarmasian 2(2): 3440.

Rahmawati, Widiastuti H, Sulistya E. 2020. In vitro antiinflammatory assay of bitter melon (Momordica charantia L.) ethanol extract. Jurnal Fitofarmaka Indonesia 7(3): 1-4.

Silalahi M, Nisyawati, Walujo EB, Supriatna J, Mangunwardoyo W. 2015. The Local Knowledge of Medicinal Plants Trader and Diversity of Medicinal Plants in the Kabanjahe Traditional Market, North Sumatra, Indonesia. Journal of Ethnopharmacology 175: 432-443.

Sridana IN. 2019. Peramalan Penyakit atau Cara Mendiagnosis suatu Penyakit dalam Usadha Bali. https://www.herbalusadabali.com/artikel/Peramalan\%2 Openyakit\%20menurut\%20Usadha\%20Bali.html (diakses 10 Oktober 2020).

Sudiasta IGB, Suwidja IK. 1991. Terjemahan dan Kajian Usada Tenung Tanya Lara. Departemen Pendidikan dan Kebudayaan Direktorat Jenderal Kebudayaan Direktorat Sejarah dan Nilai Tradisional Proyek Penelitian dan Pengkajian Kebudayaan Nusantara 1991-1992.

Sujarwo W, Keim AP, Savo V, Guarrera PM, Caneva G. 2015. Ethnobotanical study of Loloh: Traditional herbal drinks from Bali (Indonesia). Journal of Ethnopharmacology 169(1): 34-48.

Sujarwo W, Arinasa IBK, Caneva G, Guarrera PM. 2016. Traditional knowledge of wild and semi-wild edible plants used in Bali (Indonesia) to maintain biological and cultural diversity. Plant Biosystems - An International Journal Dealing with all Aspects of Plant Biology 150(5): 971-976.

Sujarwo W, Caneva G, Zuccarello V. 2020. Patterns of plant use in religious offerings in Bali (Indonesia). Acta Botanica Brasilica 34(1): 40-53.

Sukersa IW, Suardiana IW, Sulibra IKN, Tangkas MRU, Suteja IW, Yasa PEG, Jirnaya IK, Suarka IN, Putra IBR, Puspawati LP, Suastika IM, Wijana IM, Sukartha IN. 2017. Prabhajnana: Kajian Pustaka Lontar Universitas Udayana. Swasta Nulus, Denpasar Bali.

Sutrisna INGT, Widyastuti NLG, Cahyadi KD. 2019. Kajian pengobatan tradisional cacar menurut terjemahan lontar usada kacacar. Jurnal Riset Kefarmasian Indonesia 1(1): 41-55.
Takhajan A. 1986. Floristic Regions of The World. University California Press, Barkeley.

Taylor L. 2002. Technical Data Report for Bitter Melon (Momordica charantia) preprinted for Herbal Secrets of the Rainforest, 2nd ed. Sage Press, Austin.

Tcheghebe OT, Maffo M, Armel JS, Francis NT. 2016. Ethnobotanical uses, phytochemical and pharmacological profiles, and cultural value of Momordica charantia Linn.: An overview. Global Journal of Medicinal Plant Research 4(4): 23-39.

Tengah IGP, Arka IW, Sritamin NM, Gotama IBK, Sihombing H. 1995. Studi tentang: Inventarisasi, Determinasi dan Cara Penggunaan Tanaman Obat pada "Lontar Usada" di Bali. Puslitbang Farmasi Balitbang Kesehatan Departemen Kesehatan Republik Indonesia, Jakarta.

Tjokropranoto R, Rosnaeni, Nathania MY. 2011. Daya anthelmintik pengaruh ekstrak etanol daun pare (Momordica charantia L.) terhadap cacing Ascaris suum betina in vitro. Jurnal Medika Planta 1(4): 33-39.

Virdi J, Sivakami S, Shahani S, Suthar AC, Banavalikar MM, Biyani MK. 2003. Antihyperglycemic effects of three extracts from Momordica charantia. Journal of Ethnopharmacology 88(1): 107-111.

Wahidah BF, Husain F. 2018. Etnobotani tumbuhan obat yang dimanfaatkan oleh masyarakat desa Samata kecamatan Somba Opu kabupaten Gowa Sulawesi Selatan. Life Science 7(2): 56-65.

Weber A. 2014. Bitter fruits of accumulation: the case of Caspar Georg Carl Reindwardt (1773-1854). History of Science 52(3): 297-318.

Yama OE, Duru FI. 2011. Temporal adaptation in the testes of rat administered single dose Momordica charantia for three interrupted spermatogenic cycles: Cytometric quantification. Middle East Fertility Society Journal 16(3): 194-199.

Yama OE, Duru Fl, Oremosu AA, Osinubi AA, Noronha CCOkanlawon AO. 2011. Sperm quotient in SpragueDawley rats fed graded doses of seed extract of Momordica charantia. Middle East Fertility Society Journal 16(2): 154-158.

Yang SJ, Choi JM, Park SE, Rhee EJ, Lee WY, Oh KW, Park SW, Park CY. 2015. Preventive effects of bitter melon (Momordica charantia) against insulin resistance and diabetes are associated with the inhibition of NF-KB and JNK pathways in high-fat-fed OLETF rats. The Journal of Nutritional Biochemistry 26(3): 234-240.

Yesilada, Gurbuz El, Shibata H. 1999. Screening of Turkish antiulcerogenic folk remedies for anti-Helicobacter pylori activity. Journal of Ethnopharmacology 66: 289293.

Yue J, Sun Y, Xu J, Cao J, Chen G, Zhang H, Zhang X, Zhao Y. 2019. Cucurbitane triterpenoids from the fruit of Momordica charantia L. and their anti-hepatic fibrosis and antihepatoma activities. Phytochemistry 157: 21-27. 